\title{
Evaluation and Characterization of Genetically Modified Cotton Gossypium herbaceum var. Jayadhar for Helicoverpa armigera Resistance
}

\author{
Sonam Mahawar, I.S. Katageri* and M.P. Jadhav \\ Department of Biotechnology, University of Agricultural Sciences, \\ Dharwad - 580 005, Karnataka, India \\ *Corresponding author
}

\section{A B S T R A C T}

\begin{tabular}{|c|c|}
\hline $\begin{array}{l}\text { Ke y w o r d s } \\
\text { Cotton, Transgenic, } \\
\text { Cry1 Ac protein, } \\
\text { Insect bioassay. }\end{array}$ & $\begin{array}{l}\text { Previously generated genetically modified } 22(\mathrm{~J} 2-\mathrm{J} 24) \text { cotton transgenic } \\
\text { events expresses Bacillus thuringiensis }(\mathrm{Bt}) \text { derived Cry1Ac protein were } \\
\text { evaluated for their performance in the field trial during } 2014-15 \text {. Event } \mathrm{J} 8 \\
(2.23 \mu \mathrm{g} / \mathrm{g}) \text { showed the highest accumulation of Cry1Ac protein. The }\end{array}$ \\
\hline Article Info & maximum cumulative larval mortality reached up to 76.16 per cent in $\mathrm{Bt}$ \\
\hline $\begin{array}{l}\text { Accepted: } \\
19 \text { October } 2017 \\
\text { Available Online: } \\
10 \text { December } 2017\end{array}$ & $\begin{array}{l}\text { Jayadhar } \mathrm{J} 2 \text { event, compared to the negative control which stood at absolute } \\
\text { zero as expected. The Bt Jayadhar events were further evaluated for the } \\
\text { yield parameters, fibre quality and to confirm presence of cry } 1 \text { Ac gene } \\
\text { providing resistance against } H \text {. armigera. }\end{array}$ \\
\hline
\end{tabular}

\section{Introduction}

Cotton (Gossypium spp.) is the most important textile fiber crop and the world's second important oilseed crop after soybean. It occupies a predominant position among all the cash crops in India and has retained its unique fame as the "King of Fiber" and the "White Gold" because of its higher economic value among all the cash crops. In 2015-16 recorded productivity was $527.49 \mathrm{~kg}$ per lint hectare; however, still lower than the world average of about 701 to $766 \mathrm{~kg}$ per hectare and the production was 6.21 million tons against the world's total production of 21.81 million tons. Karnataka is one of the major cotton producing crop which occupies 0.59 million hectares area with the production of 0.41 million tons and $695.06 \mathrm{~kg}$ per hectares productivity. (CAB and ICAC Cotton, July,
2016). In Karnataka the Bt cotton growing area was 6 per cent in 2002, and it get consistently increased over a period of time. Cotton crop is infested by more than 160 species of insects of which bollworm infestation results in severe yield loss and majority of the farmers depend upon the use of chemical insecticides. The sucking pest complex comprising of aphids, jassids, thrips, and whitefly are widespread and fairly serious. The bollworm, Helicoverpa armigera (Hübner (Lepidoptera: Noctuidae) is one of the most devastating insect pests worldwide, infesting about 300 plant species (Sarate et al., 2012). Due to Bt cotton cultivation there is an improvement in the yield level by reducing the incidence of bollworms. It reduced the use of pesticides resulting in a 
reduction of cost of cultivation (Bengi et al., 2015). It also resulted in increase in cotton area and helps in promoting eco-friendly cultivation of cotton resulting in reduction of environmental pollution and health hazard risks which helps in better cotton production.

In Karnataka, a vast tract of dry land and dry farming areas occur starting from Dharwad to Raichur and in this belt Desi cotton Gossypium herbaceum var. Jayadhar is cultivated. At least 60 per cent of the land that every farmer owned was set aside for growing Jayadhar cotton. In these varieties farmers are never using any insecticides with a notion that they are resistant to insect pests along with moisture stress as they are Desi cotton. However, it is not true. Desi cotton although known for resistance to sucking pests and moisture stress but are highly susceptible to bollworms. As a result of this, presently the yield level of Jayadhar cotton has come down to $1-2 \mathrm{q} / \mathrm{ha}$ as against potential yield $8-10$ q/ha.

Therefore, transfer of $B t$ gene like cry $1 \mathrm{Ac}$ may make this variety resistant to bollworms benefiting the farmers in the said cropping systems. Hence, in present study twenty-two most promising transgenic lines (events) generated during 2010-11 were evaluated in both transgenic greenhouse and open field contained condition with the permission of Review Committee on Genetic Manipulation (RCGM) during 2014-15.

\section{Materials and Methods}

\section{Experimental site}

Field experiment was conducted during rabi 2014-15 at University of Agricultural Sciences, Agriculture Research Station, Dharwad. An investigation was carried to evaluate J2-J24 different Jayadhar Bt cotton lines generated as independent transgenic lines referring as event for their performance in the field trial following Randomized Block Design (RBD). Experimental plots consisted of black cotton soil and were homogeneous with respect to nutrient status and leveled by harrowing with a spacing of $90 \mathrm{~cm}$ X $20 \mathrm{~cm}$, fertilized with $\mathrm{N}: \mathrm{P}_{2} \mathrm{O}_{5}: \mathrm{K}_{2} \mathrm{O} @$ 80:40:40 kg per ha.

\section{Plant material}

The plant material consisted of genetically transformed lines of Jayadhar (G. herbaceum) cotton containing cry 1 Ac gene. These lines of Jayadhar were developed through shoot apical meristem method of genetic transformation using Agrobacterium tumefaciens as vector containing cry 1 Ac gene during the year 201011 at University of Agricultural Sciences, Agricultural Research Station, Dharwad Farm.

\section{Gene construct}

The disarmed Agrobacterium strain EHA-105 harbouring binary vector $\mathrm{pBinAR}$, carrying cry1Ac gene cloned between CaMV35S promoter and OCS terminator $I I$ and $n p t ~ I I$ gene under selectable marker, nopaline synthase (nos) promoter and terminator was obtained from National Research Centre on Plant Biotechnology, IARI, New Delhi was used (Fig. 1).

\section{PCR screening}

Genomic DNA was extracted with CTAB method according to Doyle and Doyle (1990) with few modifications. To confirm the presence of a gene in genetically transformed plants of Jayadhar, PCR analysis was carried out using the following pair of gene-specific primers (Fig. 2).

Sigma $\quad 1.1 \quad \mathrm{~kb} \quad$ Forward $\quad-5^{\prime}$ CCCAGAAGTTGAAGTACTTGGTGG 3' 
Reverse- 5' CCGATATTGAAGGGTCTTCT GTAC 3'

The annealing temperature used for the binding of the forward and reverse primer to the template was $58{ }^{\circ} \mathrm{C}$. The PCR reaction mixture contained Taq DNA polymerase (New England BioLabs), Taq Buffer (1X) (New England BioLabs), dNTPs (Bangalore Genei), $\mathrm{MgCl}_{2}$ (Bangalore Genei) and Eppendorf Gradient PCR (Germany) were used for cyclic amplification of DNA.

\section{Cry protein estimation using ELISA}

The quantitative estimation of Cry protein in putative transgenic lines was carried out at 60 days after sowing (DAS) using the Cry1Ac EnviroLogix QuantiPlate ELISA kit as per manufacturer's protocol with few modifications. It was a "sandwich" Enzyme linked Immunosorbent Assay.

\section{Insect bioassay}

To perform the insect bio-assay studies, larvae of Helicoverpa armigera (Hubner) were reared in the laboratory on artificial diet under controlled laboratory conditions at $26 \pm$ $1{ }^{\circ} \mathrm{C}, 60-70$ per cent relative humidity, and photoperiod of 16:8 $\mathrm{h}(\mathrm{L} / \mathrm{D})$ in the insectrearing laboratory at Agricultural Research Station, Dharwad farm.

Fully expanded fourth leaf from second to third nodes below terminal end from 60 DAS transgenic plants were excised and leaf petiole/stalk was inserted in the agar media in the petri plates to maintain moisture in the bioassay petri plates. On each leaf, 10 neonate larvae were released and observations were recorded at different interval $(12,24,36,48$ and 72 hours). Per cent insect mortality was calculated to obtained bio-efficacy of cry $1 \mathrm{Ac}$ gene in cotton leaves using formula as follows.
Per cent mortality $=$ (number of dead larvae/ number of larvae released) X 100

Treatment mortality - Control mortality Corrected per cent mortality = ---------- X 100

100- Control mortality

With the intention of selecting the higher resistance imparting transgenic event along with the superior yield quality, yield parameters (boll number, boll weight, seed cotton yield per plant, seed index, lint index and ginning out turn) were recorded. Fiber quality of any of the cultivar is also deciding trait towards its adaptability by the farmers. Hence, fiber quality traits such as fiber length, uniformity ratio, fiber fineness, fiber maturity ratio, fiber strength, and fiber elongation were also recorded.

\section{Junction Seq - DNA flanking sequence identification and mapping for GMO events}

This experiment carried out using the advanced NGS technologies and bioinformatics tools at SciGenom Alexandria Center for Technology, Turkapally, Hyderabad - 500078.

\section{Results and Discussion}

In several studies it was recorded that minimum quantity of Cry1 Ac protein required for killing the insect was $4.1 \mathrm{ng} / \mathrm{g}$ (Singh et al., 2015) and according to Kranthi et al., (2005) for durable pest resistance, Bt toxin @ $1.8 \mu \mathrm{g} / \mathrm{g}$ or higher is recommended.

The gene expression can be studied at the transcriptional and translational level using reverse transcriptase PCR (RT-PCR) and enzyme linked immunosorbent assay (ELISA) respectively. A transgenic cotton variety differs in the amount of Cry1Ac expressed throughout the growing season. 


\section{Gene expression}

Estimation of Cry1Ac protein in the different transgenic progenies was carried out at 60 DAS using Cry1Ac EnviroLogix QuantiPlate ELISA kit. Plant in $\mathrm{T}_{4}$ generation at $60 \mathrm{DAS}$ showed Cry1Ac protein expression as measured by quantitative ELISA in range of $0.65-2.23 \mu \mathrm{g} / \mathrm{g}$.

The transgenic event J8 $(2.23 \mu \mathrm{g} / \mathrm{g})$ showed highest accumulation of Cry protein followed by $\mathrm{J} 2(1.68 \mu \mathrm{g} / \mathrm{g})$ (Table 1) Cry protein accumulation between events of Jayadhar were varying significantly. All the $\mathrm{Bt}$ Jayadhar events showed crylAc gene expression at the protein level in ELISA. Non-Bt Jayadhar plants were taken as control, which did not show any positive results in ELISA.

\section{Insect bioassay}

The effectiveness of gene expression can be effectively understood by actual insect feeding studies through leaf detached bioassay method (Bhaksh et al., 2009). Highest cumulative insect mortality was recorded in event $\mathrm{J} 2(76.16 \%)$ followed by $\mathrm{J} 12$ (63.59 \%) and J13 (63.08 \%) (Fig. 3; Table 2). The cumulative per cent mortality recorded after 12 hours (14.63\%), 24 hours $(24.61 \%)$ and after 36 hours $(32.53 \%)$ were significantly differing from each other.

Bhattacharya et al., 2002 showed significant larval mortality ranging from 51.84 to 74.06 per cent and 70-90 per cent (Bhaksh et al., 2009). In previous several studies on checking the efficacy of transgenic events using insect bioassay (Henneberry et al., 2001; Graham et al., 2001; Mandaokar et al., 2000) stated that the highest level of mortality founds at 24 and 48 hours after feeding infestation. It could be because the activity of the CrylAc protein is more during this time period.

\section{Evaluation of Bt cotton lines for yield parameters and fibre quality traits}

The number of bolls harvested per plant observed in the transgenic lines was found significantly higher than the non-transgenic lines. This strictly indicates that Cry1Ac protein secretion in bolls leads to less infestation of the insects on it. It directly turns into increasing the yield of these lines. Event J2 (13.00) and J8 (12.73) can be considered as best events with respect to the number of bolls harvested (Graph 2). Also, the boll weight of $\mathrm{Bt}$ Jayadhar was found to be significantly more than that of non-Bt Jayadhar when compared to overall boll weight (Graph 1). The seed cotton yield/plant obtained was highest in $\mathrm{J} 2(37.18 \mathrm{~g}) \mathrm{Bt}$ Jayadhar event compared to the non-Bt Jayadhar (10.71 g) which shows the significant difference in yield while GOT per cent, lint index and seed index was not much different between the $\mathrm{Bt}$ and non-Bt Jayadhar (Table 3). This is because only healthy unaffected bolls were collected from both Bt and non-Bt Jayadhar lines. Actually, increase or decrease in yield depends on the yield loss of the non-transgenic counterparts under the same cropping practice (Qaim and Zilberman, 2003). Many reports also support present study that the yield performance of seed cotton in case of Bt genotypes are higher than non-Bt genotypes ( $\mathrm{Pal}$ et al., 2010; Bennet et a1., 2006; Saleem et al., 2010; Devi and Reddy, 2012) because of transgene present in genotypes which offers protection from bollworm attack (Khadi et al., 2008).

Fibre quality characters for Bt Jayadhar events were analyzed using HVI (High Volume Instrument) at Central Institute for Research on Cotton Technology (CIRCOT), regional quality evaluation unit situated at A.R.S., Dharwad farm. It was found that there was not much difference between Bt Jayadhar and non-Bt Jayadhar for fibre quality traits. 
Table.1 Quantitative estimation of Cry1Ac protein in Jayadhar Bt cotton events during 2014-2015

\begin{tabular}{|c|c|c|c|}
\hline S.No. & Events (lines) & $\begin{array}{l}\text { Cry1Ac protein in greenhouse } \\
\text { grown plants }\end{array}$ & $\begin{array}{l}\text { Cry1Ac protein in field } \\
\text { grown plants }\end{array}$ \\
\hline 1 & $\mathrm{~J} 2$ & 1.00 & 1.68 \\
\hline 2 & $\mathrm{~J} 3$ & 0.75 & 0.90 \\
\hline 3 & $\mathrm{~J} 4$ & 0.78 & 1.10 \\
\hline 4 & $\mathrm{~J} 5$ & 0.91 & 1.06 \\
\hline 5 & J6 & 0.70 & 0.85 \\
\hline 6 & $\mathrm{~J} 7$ & 0.65 & 0.65 \\
\hline 7 & J8 & 1.50 & 2.23 \\
\hline 8 & J9 & 0.64 & 0.91 \\
\hline 9 & $\mathrm{~J} 10$ & 0.80 & 0.95 \\
\hline 10 & $\mathrm{~J} 11$ & 0.67 & 0.94 \\
\hline 11 & $\mathrm{~J} 12$ & 0.70 & 1.28 \\
\hline 12 & $\mathrm{~J} 13$ & 0.68 & 0.90 \\
\hline 13 & $\mathrm{~J} 14$ & 0.62 & 0.95 \\
\hline 14 & $\mathrm{~J} 15$ & 1.03 & 1.11 \\
\hline 15 & $\mathrm{~J} 16$ & 0.74 & 0.95 \\
\hline 16 & $\mathrm{~J} 17$ & 0.72 & 0.75 \\
\hline 17 & $\mathrm{~J} 18$ & 0.87 & 1.01 \\
\hline 18 & J19 & 0.85 & 1.06 \\
\hline 19 & $\mathrm{~J} 20$ & 0.62 & 0.94 \\
\hline 20 & $\mathrm{~J} 21$ & 0.67 & 0.90 \\
\hline \multirow[t]{4}{*}{21} & Non-GM & 0.05 & 0.03 \\
\hline & S.Em \pm & 0.04 & 0.05 \\
\hline & C.D. $(\mathrm{P}=0.01)$ & 0.14 & 0.19 \\
\hline & C.V. (\%) & 13.83 & 14.25 \\
\hline
\end{tabular}


Table.2 Cumulative corrected per cent mortality of Helicoverpa armigera in transgenic events of G. herbaceaum var. Jayadhar

\begin{tabular}{|c|c|c|c|c|c|}
\hline Events & 12 hours & 24 hours & 36 hours & 48 hours & 72 hours \\
\hline $\mathrm{J} 2$ & 44.12 & 53.39 & 64.73 & 76.16 & 76.16 \\
\hline $\mathrm{J} 3$ & 6.16 & 21.83 & 30.49 & 47.39 & 47.39 \\
\hline J5 & 18.77 & 32.35 & 43.92 & 49.98 & 60.49 \\
\hline J6 & 6.16 & 24.89 & 32.87 & 39.98 & 42.57 \\
\hline J7 & 27.07 & 36.75 & 46.04 & 49.81 & 52.22 \\
\hline $\mathrm{J} 8$ & 31.5 & 43.06 & 48.17 & 54.98 & 54.98 \\
\hline J9 & 12.29 & 26.93 & 41.74 & 49.98 & 55.49 \\
\hline $\mathrm{J} 11$ & 0.03 & 12.64 & 25.23 & 22.59 & 31.89 \\
\hline $\mathrm{J} 12$ & 21.48 & 27.59 & 32.87 & 49.98 & 63.59 \\
\hline $\mathrm{J} 13$ & 24.19 & 27.59 & 35.25 & 54.81 & 63.08 \\
\hline $\mathrm{J} 14$ & 6.16 & 6.16 & 6.50 & 21.90 & 28.79 \\
\hline $\mathrm{J} 15$ & 0.03 & 8.87 & 24.73 & 29.48 & 32.06 \\
\hline $\mathrm{J} 16$ & 0.03 & 12.64 & 21.12 & 34.48 & 42.40 \\
\hline $\mathrm{J} 18$ & 21.48 & 34.53 & 34.35 & 39.98 & 54.98 \\
\hline Non-GM & 0.00 & 0.00 & 0.00 & 0.00 & 0.00 \\
\hline \multirow[t]{2}{*}{ Mean } & 14.63 & 24.61 & 32.53 & 41.43 & 47.07 \\
\hline & & $\begin{array}{c}\text { Fact-1 } \\
\text { (events) }\end{array}$ & Fact-2 (hours) & $\begin{array}{c}\text { Interaction } \\
(1 * 2)\end{array}$ & \\
\hline \multicolumn{2}{|c|}{ S.Em \pm} & 1.27 & 2.2 & 4.93 & \\
\hline \multicolumn{2}{|c|}{ C.D. @ 0.01} & 3.52 & 6.09 & 13.66 & \\
\hline \multicolumn{2}{|c|}{ C. V. $(\%)$} & 2.74 & & & \\
\hline
\end{tabular}


Int.J.Curr.Microbiol.App.Sci (2017) 6(12): 2780-2792

Table.3 Per se performance of lines of Jayadhar cotton carrying cry1Ac gene

\begin{tabular}{|c|c|c|c|c|c|c|}
\hline Events & $\begin{array}{c}\text { Boll } \\
\text { weight } \\
\text { (g) }\end{array}$ & Bolls/plant & $\begin{array}{c}\text { Seed cotton } \\
\text { yield/plant } \\
\text { (g) }\end{array}$ & $\begin{array}{c}\text { GOT } \\
(\%)\end{array}$ & $\begin{array}{l}\text { Lint } \\
\text { index }\end{array}$ & $\begin{array}{c}\text { Seed } \\
\text { index }\end{array}$ \\
\hline $\mathrm{J} 2$ & 3.26 & 13.00 & 37.18 & 32.67 & 2.99 & 6.17 \\
\hline $\mathrm{J} 3$ & 2.50 & 11.26 & 24.45 & 29.58 & 2.03 & 4.83 \\
\hline $\mathrm{J} 4$ & 2.64 & 11.53 & 28.18 & 28.52 & 1.99 & 5.00 \\
\hline J5 & 2.56 & 12.26 & 29.53 & 28.32 & 1.84 & 4.67 \\
\hline J6 & 2.50 & 10.00 & 23.33 & 30.07 & 1.94 & 4.50 \\
\hline $\mathrm{J} 7$ & 2.50 & 12.66 & 29.60 & 27.81 & 1.99 & 5.17 \\
\hline $\mathrm{J} 8$ & 3.00 & 12.73 & 36.14 & 31.42 & 2.37 & 5.17 \\
\hline J9 & 2.73 & 11.73 & 30.10 & 30.49 & 2.27 & 5.17 \\
\hline $\mathrm{J} 10$ & 2.80 & 12.00 & 31.87 & 30.39 & 1.97 & 4.50 \\
\hline $\mathrm{J} 11$ & 2.70 & 8.46 & 21.55 & 29.59 & 2.10 & 5.00 \\
\hline $\mathrm{J} 12$ & 2.83 & 12.06 & 31.94 & 29.99 & 2.21 & 5.17 \\
\hline $\mathrm{J} 13$ & 2.56 & 12.40 & 29.51 & 28.52 & 1.93 & 4.83 \\
\hline $\mathrm{J} 14$ & 2.66 & 8.26 & 20.57 & 29.58 & 2.17 & 5.17 \\
\hline $\mathrm{J} 15$ & 2.63 & 7.80 & 19.24 & 28.65 & 2.01 & 5.00 \\
\hline $\mathrm{J} 16$ & 2.76 & 9.60 & 25.12 & 29.64 & 2.04 & 4.83 \\
\hline $\mathrm{J} 17$ & 2.83 & 7.33 & 19.57 & 29.69 & 1.83 & 4.33 \\
\hline $\mathrm{J} 18$ & 2.73 & 10.80 & 28.00 & 29.47 & 1.88 & 4.50 \\
\hline J19 & 2.76 & 8.86 & 23.05 & 29.33 & 2.21 & 5.33 \\
\hline $\mathrm{J} 20$ & 2.60 & 8.20 & 19.97 & 27.67 & 1.91 & 5.00 \\
\hline $\mathrm{J} 21$ & 2.80 & 7.66 & 20.33 & 28.23 & 1.97 & 5.00 \\
\hline $\mathrm{J} 22$ & 2.63 & 8.00 & 19.92 & 28.73 & 2.22 & 5.50 \\
\hline $\mathrm{J} 24$ & 2.70 & 7.4 & 18.82 & 29.01 & 2.18 & 5.33 \\
\hline Non-GM & 2.50 & 4.86 & 10.71 & 28.52 & 1.70 & 4.67 \\
\hline S.Em \pm & 0.05 & 0.16 & 0.94 & 0.42 & 0.05 & 0.12 \\
\hline C.D. $(P=0.01)$ & 0.16 & 0.47 & 2.83 & 1.26 & 0.15 & 0.35 \\
\hline C. V. $(\%)$ & 3.46 & 2.80 & 6.49 & 2.48 & 4.09 & 4.03 \\
\hline
\end{tabular}


Fig.1 Construct map of the binary vector pBinBt3

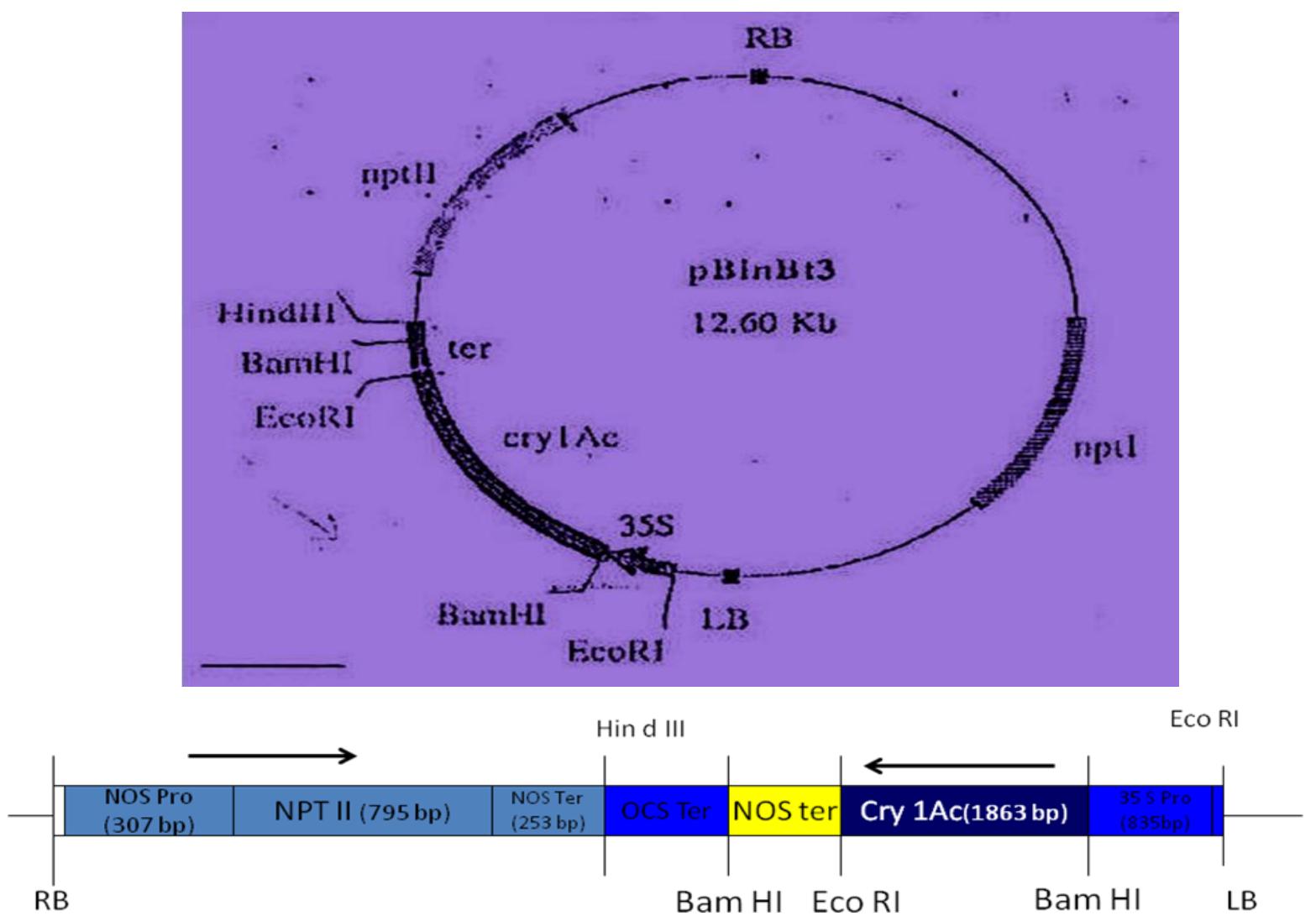

Fig.2 Confirmation of cry1Ac transgenic plants through PCR amplification

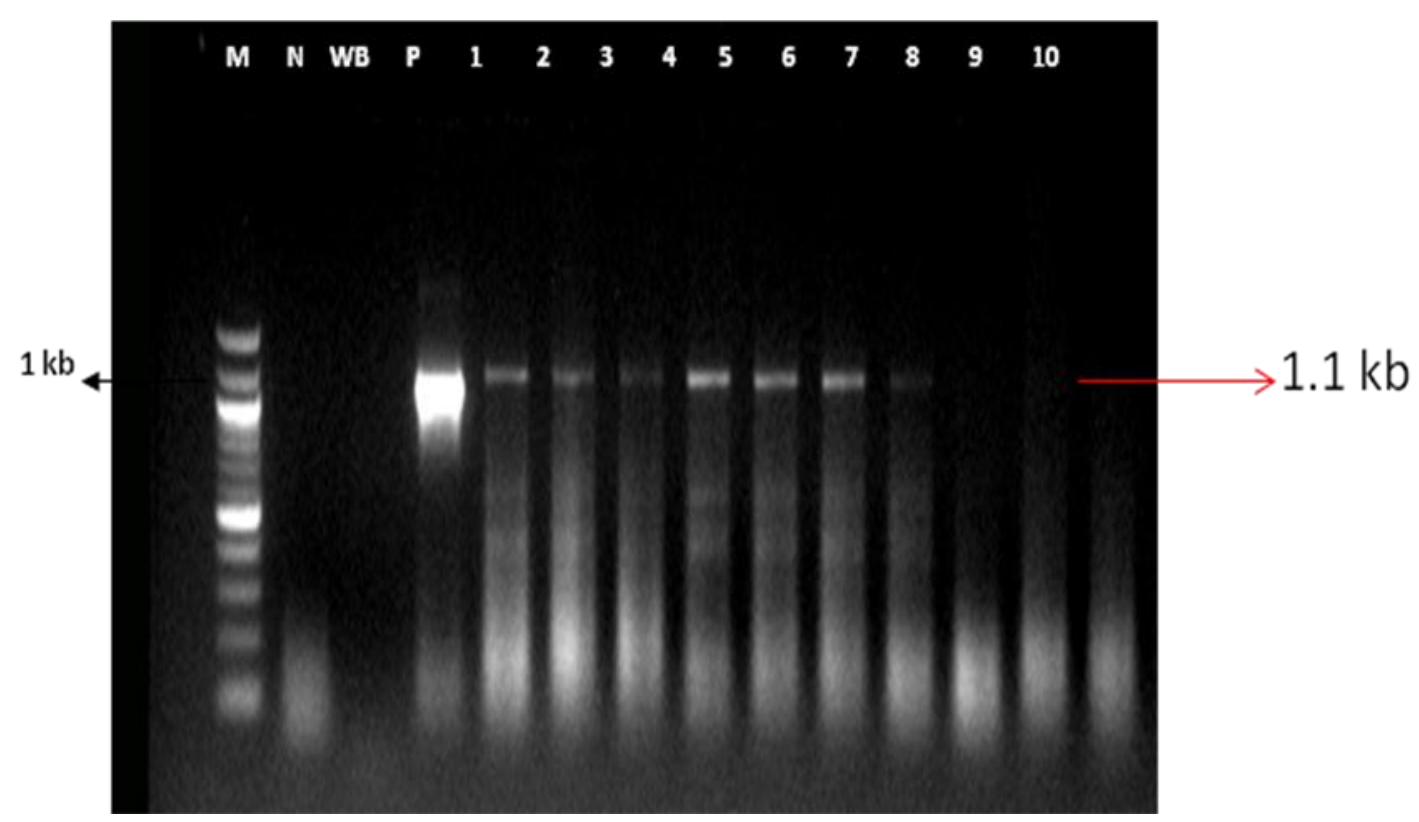

M: $1 \mathrm{~kb}$ ladder, N: Untransformed control control, WB: Reaction mixture without template DNA, P: Plasmid, Lane 1-10: transgenic plants carrying cry1Ac gene amplification in transgenic plants. 
Fig.3 Leaf feeding insect bioassay of Bt and non-Bt Jayadhar
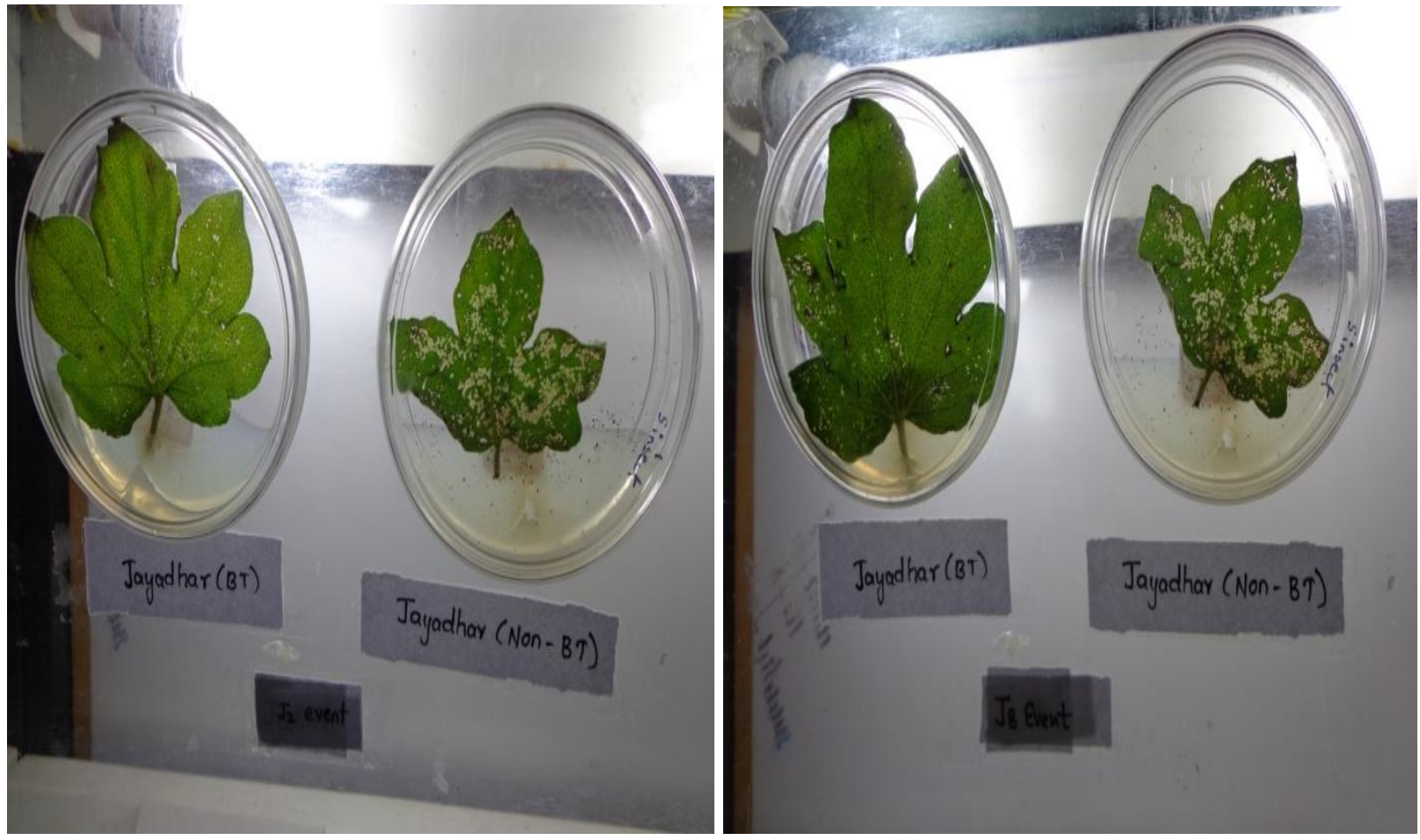

Fig.4 Jayadhar transgenic events confirmation with single primer

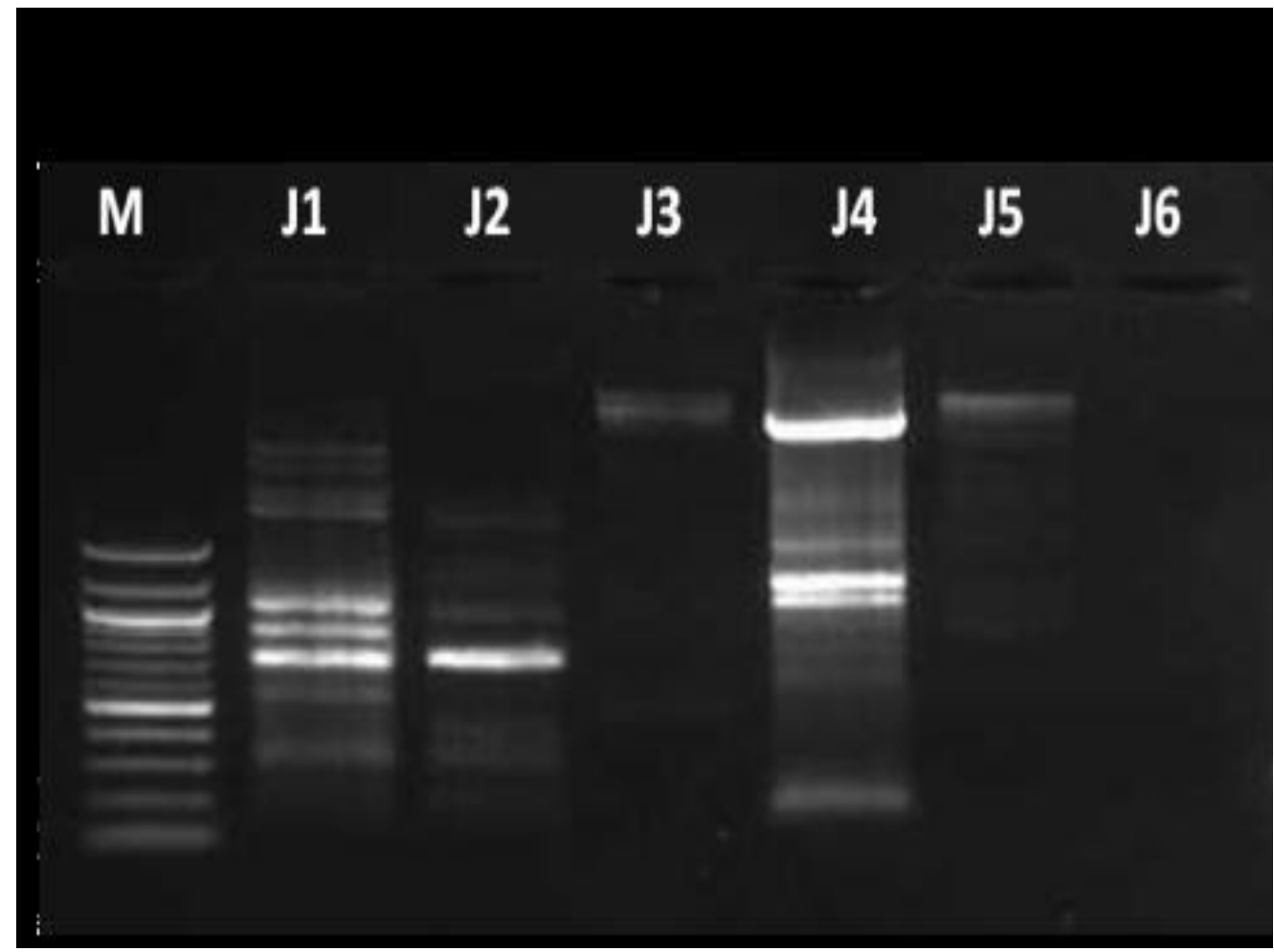

M: Marker, J1: JAY DNA+LB J1 NGS: R1C1, J2: JAY DNA+LB J1 NGS: R1C2, J3: JAY DNA+LBJ1 NGS-C1, J4: JAY DNA+LB J1: NGS-C2, J5: JAY DNA+LB J1 NGS-C3, J6: JAY DNA+LB J1 NGS-C4 
Fig.5a First combination PCR: Jaydhar Left Border with LB_F_3 and confirmation primers and control PCR with same combinations of primer

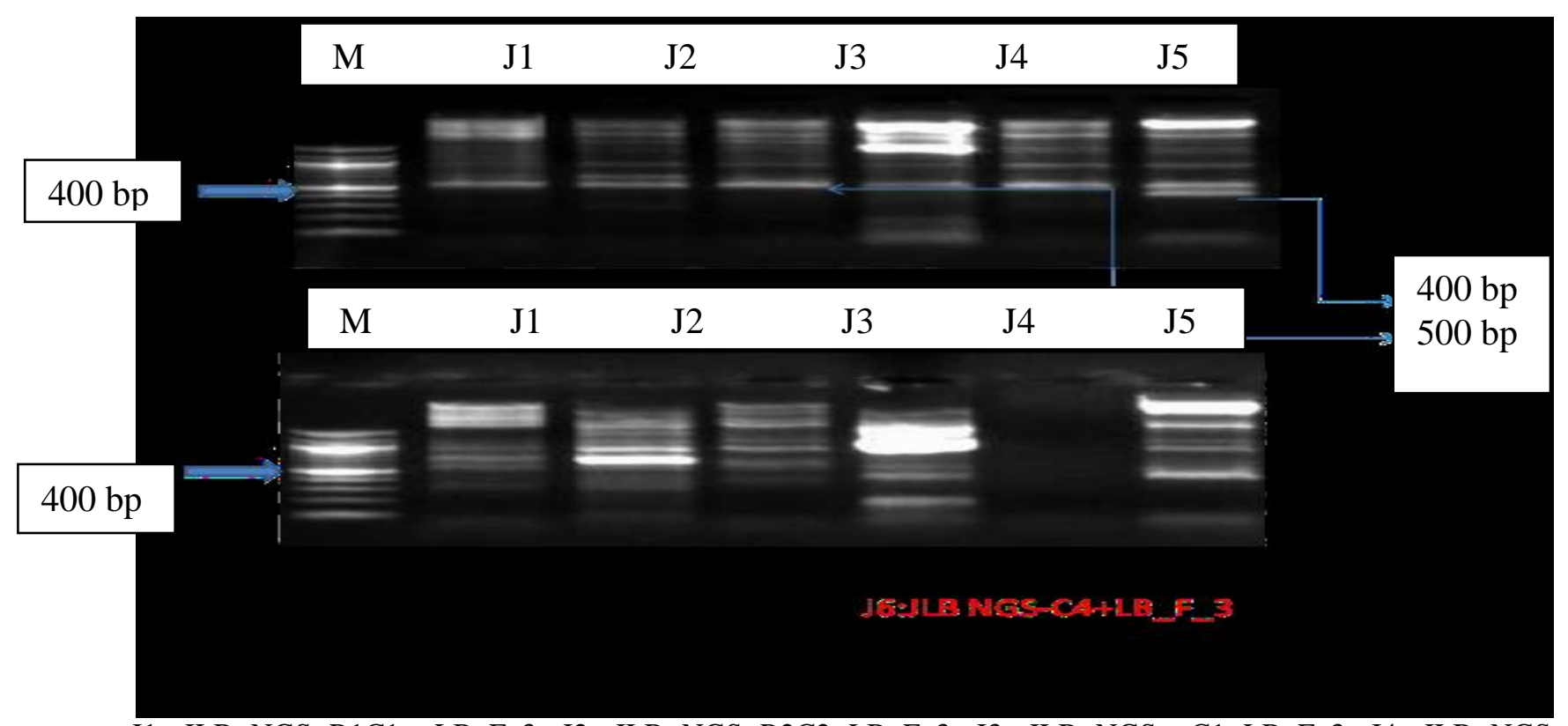

J1: JLB NGS R1C1+ LB_F_3, J2: JLB NGS R2C2+LB_F_3, J3: JLB NGS -C1+LB_F_3, J4: JLB NGSC2_LB_F_3, J5: JLB NGS-C3_LB_F_3, J6: JLB NGS-C4+LB_F_3

Fig.5b Second combination PCR: Jaydhar Left Border with pBin19 LB F2 with Jaydhar LB confirmation primers

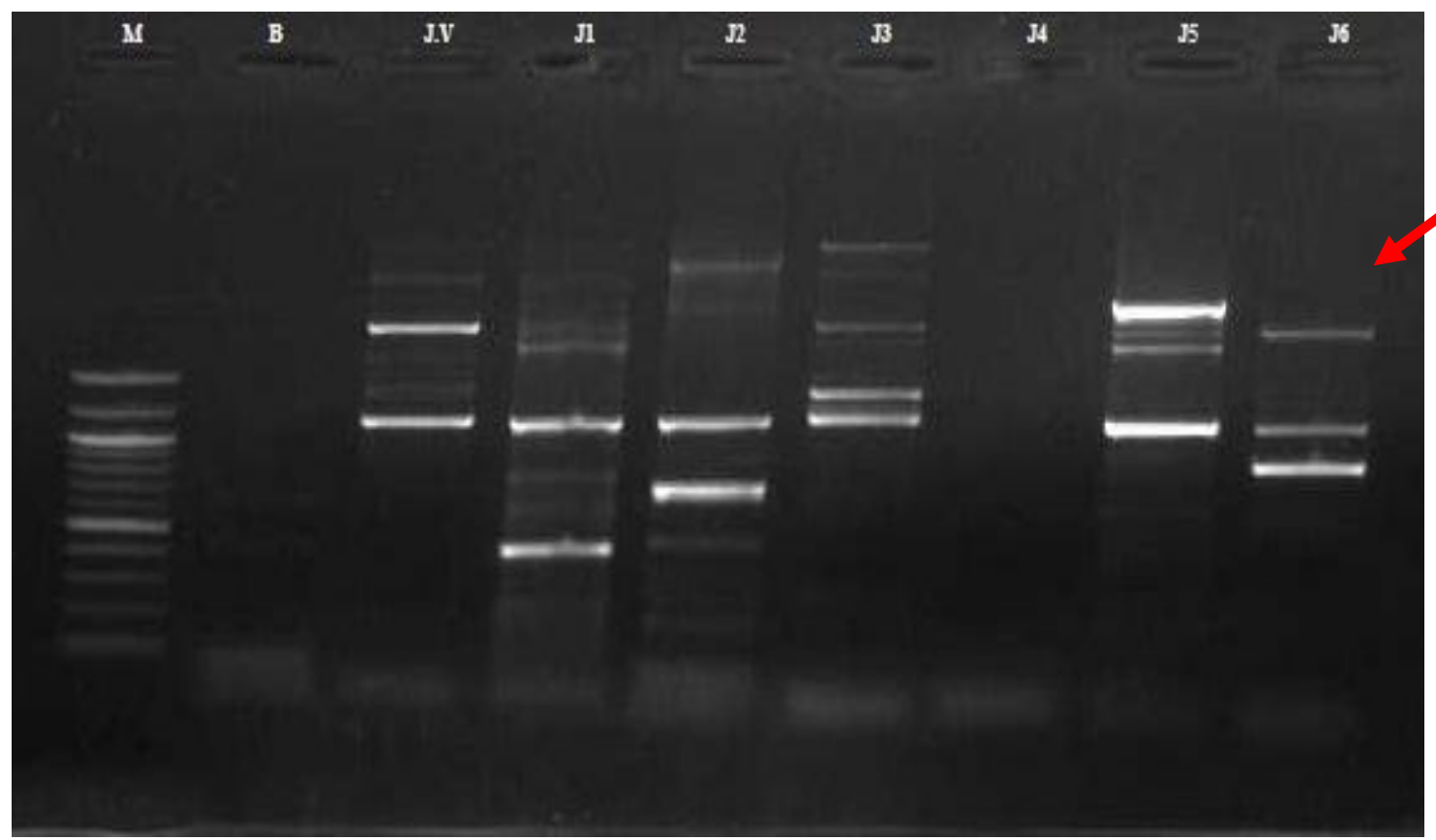

B: Blank, J.V: Jaydhar DNA with vector primer alone. J1: PBIN19 F2 + J1 LB R1C1, J2: PBIN19 F2 + J1 LB R2C2, J3: PBIN 19 F2+ J1 LB C1, J4: PBIN19 F2 + J1 LC C2, J5: PBIN19 F2 + J1 LB C3, J6: PBIN19 F2 + J1 LB $\mathrm{C} 4$ 
Fig.5c Third combination PCR: Jaydhar Left Border with gene specific and c1,c4 confirmation primers

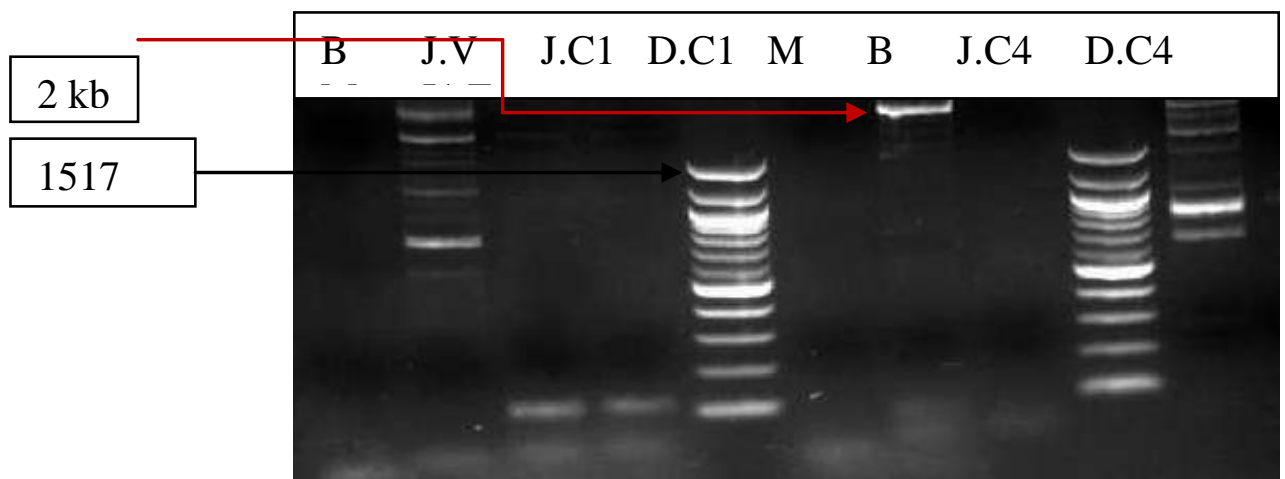

J.V: Jaydhar DNA + p Bin 19 LB F1 alone, J.C1: Jaydhar DNA+ C1 +pBin19 LBF1, D.C1: DLSA DNA+C1+pBin 19LB F1, B-Blank, J.C4: Jaydhar DNA+ C4+pBin19 LBF1, D.C1: DLSA DNA+C4+ pBin 19LB F1, J1F: Jaydhar DNA+C1+Cry1 Ac6F

Graph 1 and 2 Yield parameters (weigh of bolls and No. of bolls/plt) for Bt and non-Bt Jayadhar events
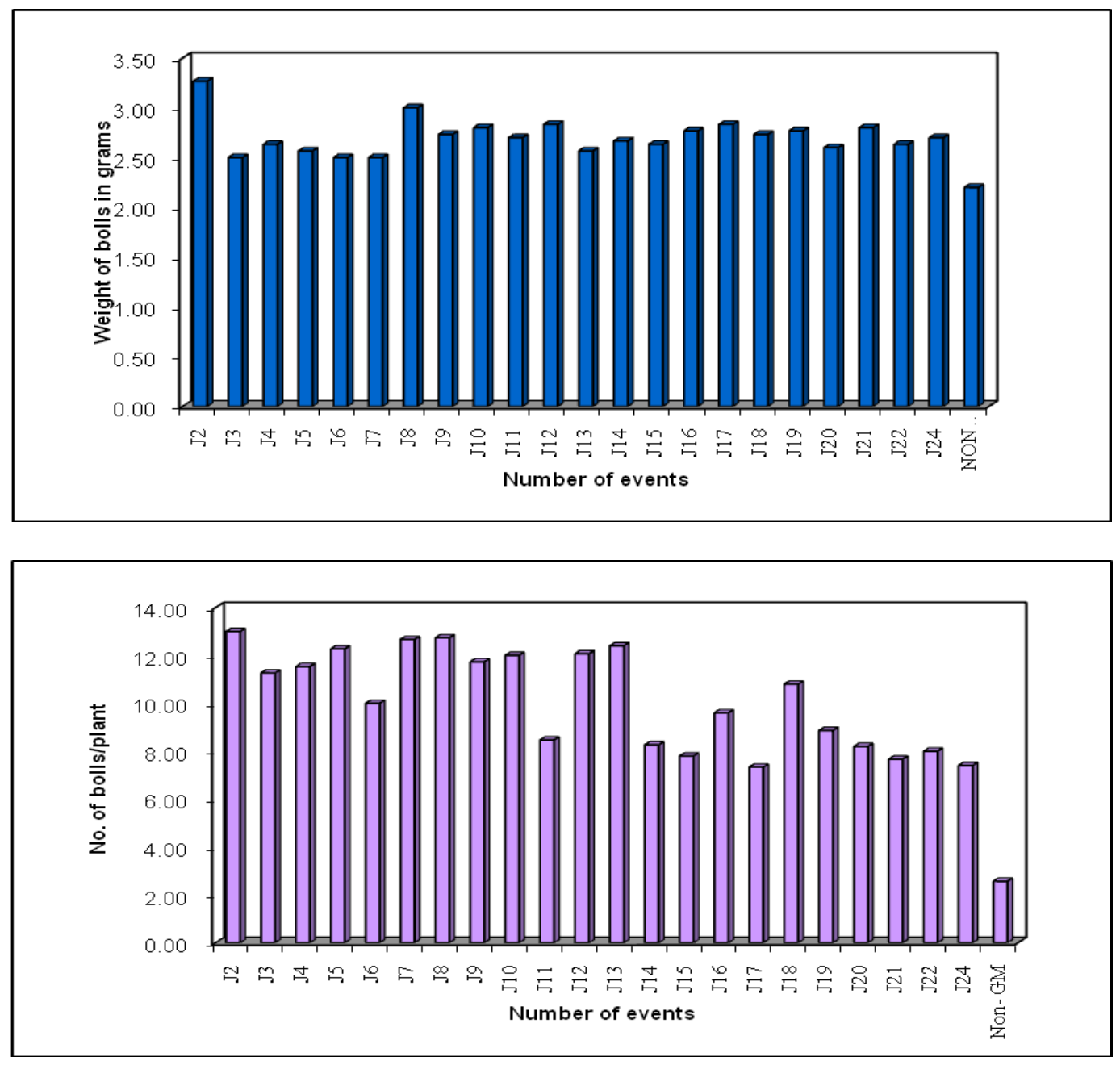
Junction Seq-DNA flanking sequence identification and mapping for GMO events

The site of insertion of T-DNA/Cry1Ac in the cotton genome was identified by recovering the genomic sequences flanking the left border (LB) of T-DNA by NGS sequencing using the reads obtained from sequencing random primer amplicon library. Primary PCR with GSP1 and random primer produced a smear in PCR product (Fig. 4 and Fig. 5a). The multiple bands were noticed in second combination PCR with nested primer 1 and GSP2 where multiple bands were diluted and primary product was used as a template (Fig. $5 b)$.

However there was a reduction in number of multiple bands produced with development of third combination PCR with GSP3 and nested primer 2 (Fig. 5c).

The bright band with approx. $1 \mathrm{~kb}$ amplicon size were eluted, cloned and sequenced for further process of refining. The amplicons obtained with the left border genomic primer was given for Sanger sequencing for confirmation of sequences.

As no reliable PCR bands were found with left or right border primer combinations we could not proceed further. However, the PCR based methods are limited by quality of DNA. In plants, the final DNA obtained from an extraction has many inhibitors like polysaccharides and polyphenolics that inhibit various enzymatic reactions. When the yield of PCR products are low due to the result of these inhibitions, Sanger sequencing can fail.

The Bt Jayadhar events $\mathrm{J} 2$ and $\mathrm{J} 8$ are promising based on insect bioassay, protein expression, and yield parameters. Large-scale verification of these two events in future may be required for commercialization.

\section{References}

Anonymous, Cotton advisory board, The Cotton Corporation of India Ltd. 2016

Arshad, M., A. Suhail, M.J. Arif and M.A. Khan, 2009, Transgenic-Bt and nontransgenic cotton effects on survival and growth of Helicoverpa armigera. Int. J. Agric. Biol., 11: 473-476

Bakhsh, A., Rao, A. Q., Shahid, A. A., Hussain, T. and Riazuddin, S., 2009, CaMV35S is a developmental promoter being temporal and spatial in expression pattern of insecticidal genes (cry $1 \mathrm{Ac}$ and cry2A) in cotton. Res. J. Cell Mol. Biol. 3: 56-62.

Benagi, V. I., Naik, K. L., Rafee, C. M., Udikeri, S. S., Gopala, M., H. Basavaraja and Patil B. C. 2015. Impact Evaluation of $\mathrm{Bt}$ cotton in Karnataka Final Report. Shri Ulavappa I. Shivoji \& Shilpa K. Sabannavar DTP Unit, Publication Centre, UAS Dharwad

Bennett, R., Kambhampati, U., Morse, S. and Ismael, Y., 2006, Farm-level economic performance of genetically modified cotton in Maharashtra, India. Rev. Agric. Econ., 1 (28):59-71.

Bhattacharya, R. C., Viswakarma, N., Bhat, S. R., Kirti, P. B. and Chopra, V. L., 2002, Development of insect resistant transgenic cabbage plants expressing a synthetic cry $1 \mathrm{Ab}$ gene from Bacillus thuringiensis. Curr. Sci., 83 (2): 146150.Devi, R. S. and Reddy, K. D., 2012, Performance of $\mathrm{Bt}$ and non-Bt cotton hybrids against American bollworm, Helicoverpa armigera (Hubner). $J$. Biopest. 5 (2): 107-112.

Doyle, J. J. and Doyle, J. L., 1990, Isolation of plant DNA from fresh tissue. Focus, 12:13-15.

Graham, H., Christopher, R. B., Mark, E. G. and Jain, J. D., 2001, Cry1Ab protein levels in phytophagous insects feeding on transgenic corn: implication for 
secondary exposure risk assessment. Entomologia Experimentalis et Applicalu, 99: 37-45.

Henneberry, T. J., Forlow, J. L. and Torre, D. L., 2001, Effects of transgenic cotton on mortality and development of pink bollworm larvae. South-Western Entomol., 26 (2): 115-128.

Khadi, B. M., Katageri, I. S. and Mogali, S.C. 2008, Performance of Bt-cotton hybrids for yield and fiber quality in transitional tract of Karnataka. Agric. Sci. Digest, 28 (4): $283-285$.

Kranthi, K. R, Naidu, S., Dhawad, C. S., Tatwawadi. A., Mate, K. and Patil, E., 2005, Temporal and intra plant variability of Cry1Ac expression in $\mathrm{Bt}$ cotton and its influence on the survival of cotton bollworm, Helicoverpa armigera (Hubner) (Noctuidae: Lepidoptera). Curr. Sci., 89: 2-25.

Mandaokar, T. A. D., Goyal, R. K., Shukla, A., Bisaria, S., Bhalla, R., Reddy,V. S., Chaurasia, A., Sharma, R. P., Altosaar, I. and Kumar, A., 2000. Transgenic tomato plants resistant to fruit borer (Helicoverpa armigera Hubner) Crop Protect., 19: 07-312.
Pal, V., Sharma, P. D., Jat, S. L. and Chauhan, R., 2010, Relative performance of Bt. and their corresponding non-Bt cotton genotypes for sucking pests and yield. J. Cotton Res. Dev., 24: 97-99.

Qaim, M. and Zilberman, D., 2003, Yield effects of genetically modified crops in developing countries. Sci., 299: 900902.

Saleem, M. F., Cheema, M. A., Bilal, M. F., Anjum, S. A., Shahid, M. Q. and Khurshid, I., 2010, Fiber quality of cotton (Gossypium Hirsutum) cultivars under different phosphorus levels. $J$. An. Plant Sci., 21: 26-30

Sarate, P. J., Tamhane, V. M., Kotkar, H. M., Rtanakaran, N., Gupta, S. and Giri, A. P., 2012, Development and digestive flexibilities in the midgut of polyphagus pest the cotton bollworm, Helicoverpa armigera. J. Insect. Sci., 12: 12-42

Singh, V. K., Nain, V., Sharma, P., Rao, K. R. S. S., Birah, A., Gupta, G. P. and Kumar, P. A. 2015, Enhanced Toxicity of Purified Bacillus thuringiensis Cry1Ac Delta-endotoxin. Curr. Trends Biotechnol. Pharmacy 9(3): 243-250.

\section{How to cite this article:}

Sonam Mahawar, I.S. Katageri and Jadhav, M.P. 2017. Evaluation and Characterization of Genetically Modified Cotton Gossypium herbaceum var. Jayadhar for Helicoverpa armigera Resistance. Int.J.Curr.Microbiol.App.Sci. 6(12): 2780-2792. doi: https://doi.org/10.20546/ijcmas.2017.612.322 